\title{
Biogenic synthesis of silver nanoparticles using guava (Psidium guajava) leaf extract and its antibacterial activity against Pseudomonas aeruginosa
}

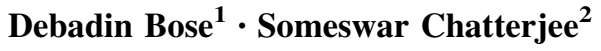

Received: 8 July 2015/ Accepted: 25 August 2015/Published online: 4 September 2015

(c) The Author(s) 2015. This article is published with open access at Springerlink.com

\begin{abstract}
Among the various inorganic nanoparticles, silver nanoparticles have received substantial attention in the field of antimicrobial research. For safe and biocompatible use of silver nanoparticles in antimicrobial research, the different biogenic routes are developed to synthesize silver nanoparticles that do not use toxic chemicals. Among those, to synthesize silver nanoparticles, the use of plant part extract becomes an emerging field because plant part acts as reducing as well as capping agent. For large-scale production of antibacterial silver nanoparticles using plant part, the synthesis route should be very simple, rapid, cost-effective and environment friendly based on easy availability and non-toxic nature of plant, stability and antibacterial potential of biosynthesized nanoparticles. In the present study, we report a very simple, rapid, cost-effective and environment friendly route for green synthesis of silver nanoparticles using guava (Psidium guajava) leaf extract as reducing as well as capping agent. This plant has been opted for the present study for its known medicinal properties, and it is easily available in all seasons and everywhere. The biosynthesized silver nanoparticles are characterized by UV-Vis and TEM analysis. The average particle size is $40 \mathrm{~nm}$ in the range of 10-90 $\mathrm{nm}$. The antibacterial activity of these nanoparticles against Pseudomonas aeruginosa MTCC 741 has been
\end{abstract}

Someswar Chatterjee

someswar_76@yahoo.com

Debadin Bose

debadin@hotmail.com

1 Department of Botany, Kabi Nazrul College, Murarai, Birbhum, WB 731219, India

2 Department of Chemistry, Kabi Nazrul College, Murarai, Birbhum, WB 731219, India measured by disc diffusion method, agar cup assay and serial dilution turbidity measurement assay. The results show that green synthesized silver nanoparticles, using guava (Psidium guajava) leaf extract, have a potential to inhibit the growth of bacteria.

Keywords Green synthesis - Ag nanoparticles . Antimicrobial activity $\cdot$ Psidium guajava $\cdot$ Pseudomonas aeruginosa MTCC 741

\section{Introduction}

Nanomaterials and nanostructures, usually ranging from 1 to $100 \mathrm{~nm}$, based on the specific characteristics such as size, morphology and distribution exhibit their remarkable potential in the field of biology and medicine. Among the various inorganic metal nanoparticles, silver $(\mathrm{Ag})$ nanoparticles have received substantial attention in the field of antimicrobial research. It may be mentioned that the antimicrobial activities of silver and silver compounds are very well known in case of dental work, catheters and burn wounds, etc.

As per demand in bioscience and biotechnology along with other field, silver nanoparticles have been synthesized by various methods such as reduction of silver compounds in solution (Wang et al. 2005), thermal decomposition of silver compounds (Navaladian et al. 2007), microwaveassisted synthesis (Sreeram et al. 2008), and laser-mediated synthesis (Zamiri et al. 2011), which are well reported. To synthesize silver nanoparticles by the reduction of $\mathrm{AgNO}_{3}$, generally sodium borohydride, citrate, ascorbate, etc. are used as reducing agents (Shirtcliffe et al. 1999; Nickel et al. 2000; Evanoff and Chumanov 2004; Sondi et al. 2003; Merga et al. 2007). It may be mentioned that in the most 
cases synthesizing nanoparticles through chemical reduction process requires high pressure and temperature and toxic chemicals. Chemical synthesis methods lead to the presence of some toxic chemicals, mainly reducing agent and/or capping agent, on the surface that may have adverse effect in the biological applications. But, for safe and biocompatible use of silver nanoparticles in bioscience and biotechnology, it is need to develop biogenic route to synthesize silver nanoparticles that do not use toxic chemicals.

In case of biosynthesis of silver nanoparticles, the environmentally benign reducing agents such as carbohydrates and polysaccharides are used (Raveendran et al. 2003). The uses of several bioorganisms to grow the silver nanoparticles have been also reported (Xie et al. 2007). The silver nanoparticles synthesis using plant (leaf) extract is an emerging field because plant part acts as reducing as well as capping agent and free from toxic chemical.

For large-scale production of antibacterial silver nanoparticles using plant part, the synthesis route should be very simple, rapid, cost-effective and environment friendly based on easy availability and non-toxic nature of plant, stability and antibacterial potential of biosynthesized nanoparticles.

Recently, the plant-mediated synthesis of silver nanoparticles using Coleus aromaticus leaf (Vanaja and Annadurai 2013), living peanut seedling (Raju et al. 2014), Petroselinum crispum leaf (Roy et al. 2014), Citrus limon leaf (Vankar and Shukla 2012), Avicennia marina mangrove plant leaf, bark and root (Gnanadesigan et al. 2012) and Justicia adhatoda L. Leaf (Bose and Chatterjee 2015) have been reported.

However, as per our knowledge, to investigate the antimicrobial properties only few number of easily available plants leaf have been used to synthesize Ag nanoparticles till now. This motivates us to search a very simple, rapid, cost-effective and environment friendly synthesis route of Ag nanoparticles, using leaf extract, for the investigation of its antimicrobial activities.

Thus, in this present study, an attempt has been done to synthesize silver nanoparticles using guava (Psidium guajava) leaf extract from the green chemistry perspective and to investigate the antimicrobial activities of these biosynthesized silver nanoparticles on Pseudomonas aeruginosa MTCC as a model gram-negative bacteria. This plant has been opted for the present study for its known medicinal properties, and it is easily available in all seasons and everywhere.

\section{Materials and methods}

\section{Preparation of plant leaf extract}

The fresh matured leaves of Psidium guajava (Fig. 1) were collected and thoroughly washed with distilled water. About $5 \mathrm{~g}$ of cleaned leaves was chopped into fine pieces then crashed with sea sand and mixed with $60 \mathrm{ml}$ of double-distilled water. The mixture was then filtered, and the filtrate was used as stock solution.

\section{Synthesis of Ag nanoparticles}

The silver nanoparticles were prepared by treating $20 \mathrm{ml}$ of $1 \mathrm{mM}$ of $\mathrm{AgNO}_{3}$ (Merck) solution with only $0.2 \mathrm{ml}$ of leaf extract and stirred for $10 \mathrm{~min}$ at $30^{\circ} \mathrm{C}$. The solution appeared light yellow colour and then changed to reddish brown colour (Fig. 2). The solution was kept at $4{ }^{\circ} \mathrm{C}$ for future use.

\section{Characterization of Ag nanoparticles}

\section{UV-Vis spectra analysis}

The noble metal silver nanoparticles exhibit unique optical properties on account of their surface plasmon resonance (SPR). The formation of Ag nanoparticles was confirmed by measuring the UV-visible spectra (Fig. 3). UV-visible spectroscopy analyses were carried out on SYSTRONICS spectrophotometer (Model-105, India) from range $350-900 \mathrm{~nm}$. The double-distilled deionized water was used as blank.

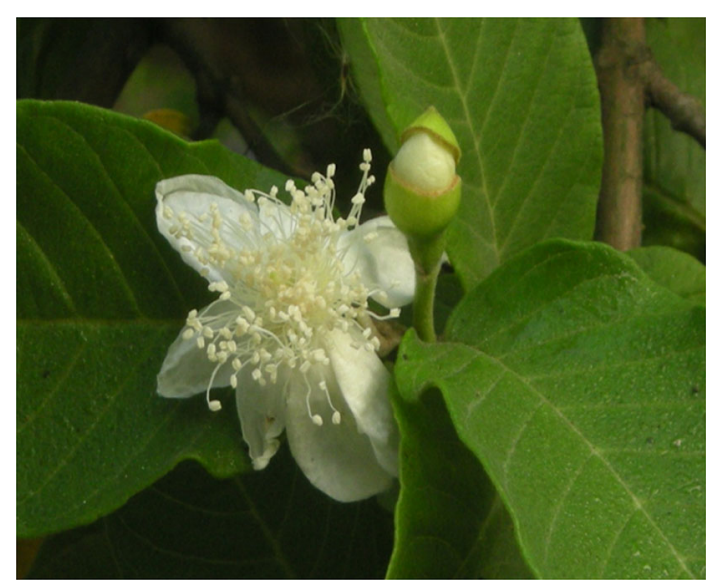

Fig. 1 Guava (Psidium guajava) leaf 


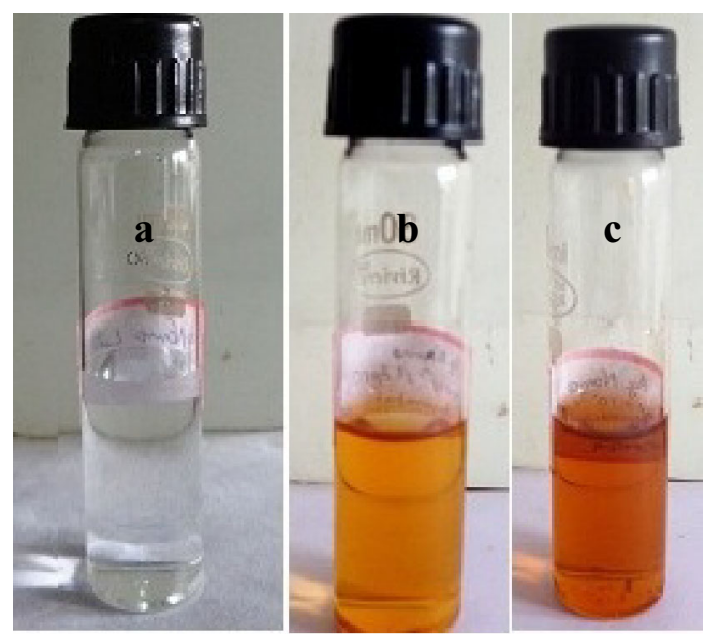

Fig. $2 \mathrm{Ag}$ nanoparticle solutions, synthesized by reducing $\mathrm{AgNO}_{3}$ using guava leaf extract. a Initial reaction mixture; $\mathbf{b}$ reaction mixture after $10 \mathrm{~min}$; c reaction mixture after $1 \mathrm{~h}$

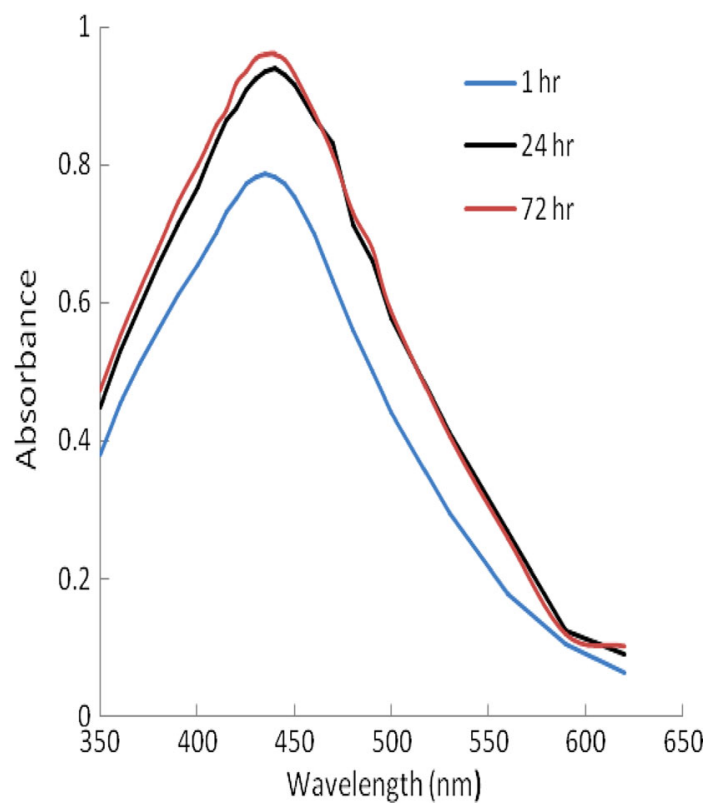

Fig. 3 UV-Vis spectra of Ag nanoparticle, synthesized by reducing $\mathrm{AgNO}_{3}$ using guava leaf extract

\section{Transmission electron microscope analysis}

TEM studies were performed using CM 12 PHILIPS operating at $100 \mathrm{kV}$. For the TEM image (Fig. 4), a drop of solution containing the nanoparticles was deposited on a $\mathrm{Cu}$ grid covered with carbon. After allowing the film to stand for $5 \mathrm{~min}$, the extra solution was removed by means of blotting paper and the grid allowed drying before the measurement.

\section{Microbiological assays}

The model gram-negative organism $P$. aeruginosa MTCC 741 strain was maintained in both nutrient agar (Hi-media, India) and nutrient broth medium (Hi-media, India) at $37{ }^{\circ} \mathrm{C}$.

For the disc diffusion method, $100 \mu \mathrm{l}$ of $24 \mathrm{~h}$ old bacterial culture was uniformly spread over the nutrient agar surface. Freshly prepared Ag nanoparticles solution-soaked sterile paper discs of $5 \mathrm{~mm}$ diameter were placed on that agar surface. The zones of inhibition (ZoI) were measured after $24 \mathrm{~h}$ incubation at $37^{\circ} \mathrm{C}$.

In case of agar cup assay, $100 \mu \mathrm{l}$ of $24 \mathrm{~h}$ old bacterial culture was uniformly spread over the nutrient agar surface. Then, $50 \mu \mathrm{l}$ of $\mathrm{Ag}$ nanoparticles solutions synthesized from three different concentrations of $\mathrm{AgNO}_{3}$ solution was added into the wells $(1 \mathrm{~cm}$ diameter) on that nutrient agar surface. The zones of inhibition (ZoI) were measured after $24 \mathrm{~h}$ incubation at $37^{\circ} \mathrm{C}$.

For serial dilution turbidity measurement assay (Fig. 5), nutrient broths were prepared and distributed in several culture tubes. Each tube contains $10 \mathrm{ml}$ of nutrient broth. The stock solution of the $\mathrm{Ag}$ nanoparticles solution was serially diluted at $10^{-1}, 10^{-2}$ and $10^{-3}$ level. The tubes were inoculated with $50 \mu \mathrm{l}$ of $24 \mathrm{~h}$ old bacterial suspension. In each tube, $1 \mathrm{ml}$ of $\mathrm{Ag}$ nanoparticles solution of different concentrations was added. The tubes were incubated for $24 \mathrm{~h}$ at $37^{\circ} \mathrm{C}$, and OD were taken at $540 \mathrm{~nm}$ to measure the turbidity against a sterile blank. A negative control without bacterium and a positive control without Ag nanoparticles were incubated for comparative purpose. All the experiments were done in triplicate.

\section{Results and discussion}

The Psidium guajava is well-known medicinal plant and leaves of its are widely used in the Ayurvedic system of medicine as well as in folk medicine (Gutiérrez et al. 2008). Guava leaf extract is used as astringent, anodyne, febrifuge, antispasmodic, tonic to treat wounds, ulcer, cholera, diarrhoea, vomiting, nephritis, toothache, gum inflammation, etc. (Ojewole 2005). Psidium guajava leaf contains leucocyanidin, flavonoids which includes quercetin, quercetin-3-O- $\alpha$-L-arabinofuranoside, quercetin-3-O$\beta$-D-arabinopyranoside, quercetin 3-O- $\beta$-D-galactoside (hyperin), quercetin-3- $O$ - $\alpha$-L-arabinofuranoside (avicularin), quercetin 3-O- $\beta$-D-glucoside(isoquercetin), plant sterol, carotenes, tannins, saponins, vitamin $\mathrm{C}$ and B6, carbohydrates and diethoxy alkenes as plasma compounds. It is reported that flavonoids (Sahadevan et al. 2013) 

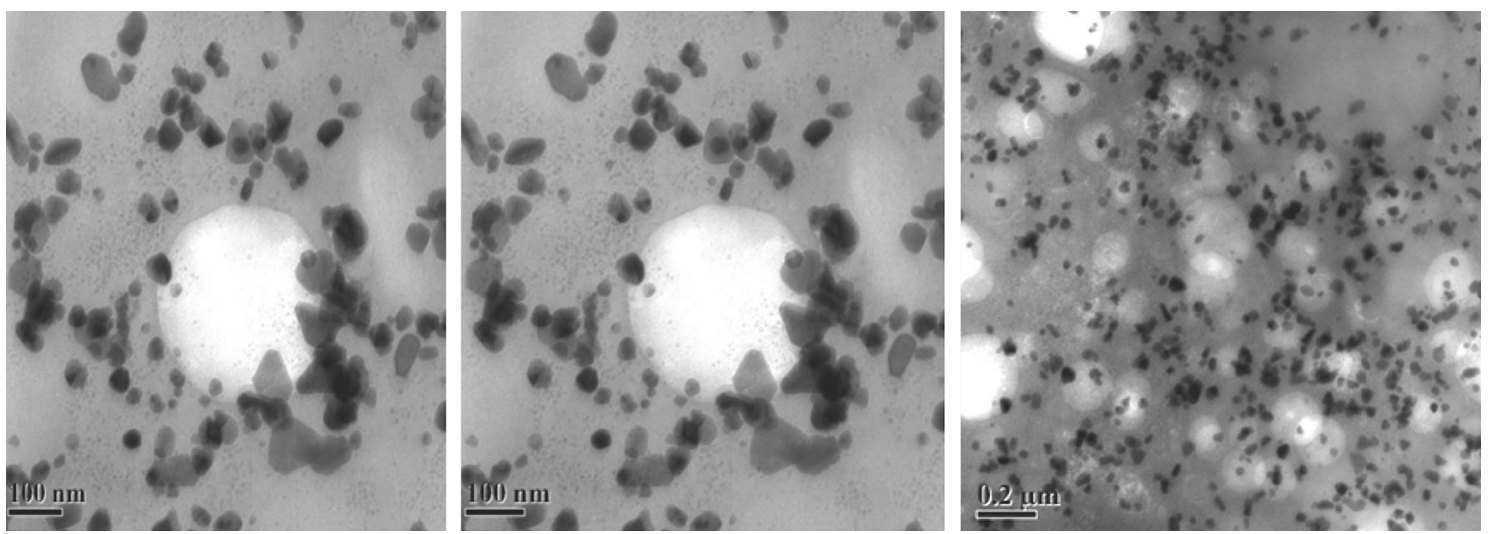

Fig. 4 TEM images of $\mathrm{Ag}$ nanoparticles synthesized from $\mathrm{AgNO}_{3}$ using guava leaf extract

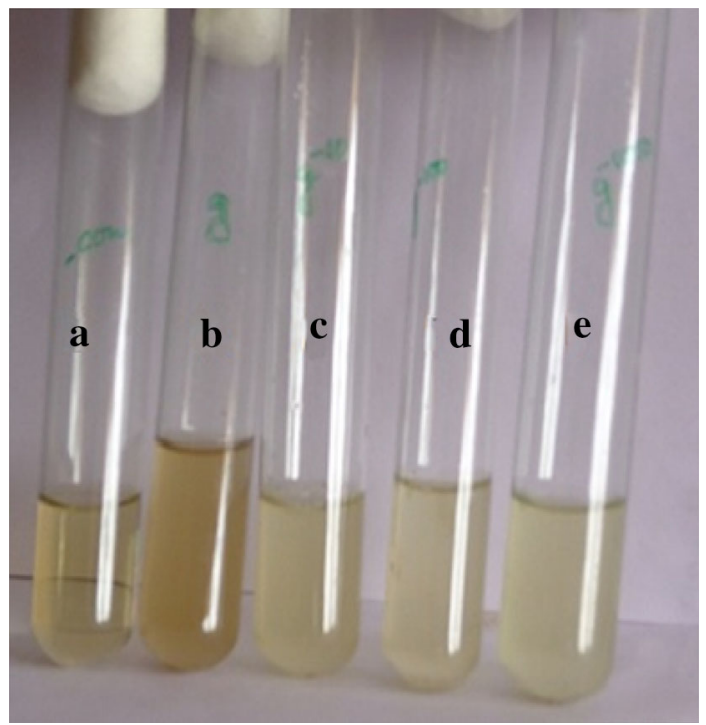

Fig. 5 Serial dilution method of antimicrobial activity assay of $\mathrm{Ag}$ nanoparticles synthesized from guava leaf extract. a (-) ve control, i.e., without inoculums, only medium with $\mathrm{Ag}$ nanoparticles are synthesized from $1 \mathrm{mM} \mathrm{AgNO}_{3}$ solution ( $\mathrm{Ag}$ nanoparticles stock solution); b bacteria with $\mathrm{Ag}$ nanoparticles stock solution; $\mathbf{c}$ bacteria with $10^{-1}$ times diluted $\mathrm{Ag}$ nanoparticles stock solution; $\mathbf{d}$ bacteria with $10^{-2}$ times diluted Ag nanoparticles stock solution; e bacteria with $10^{-3}$ times diluted Ag nanoparticles stock solution, after $24 \mathrm{~h}$ incubation

present in leaf extract are responsible for reducing $\mathrm{Ag}^{+}$ ions and capping for Ag nanoparticles. In this study, some of the flavonoids present in leaf extract may act as reducing and/or capping agent to synthesize Ag nanoparticles.

The exact mechanism of reducing the $\mathrm{Ag}^{+}$ion and capping the $\mathrm{Ag}$ nanoparticles by flavonoids is not well established. It has been believed (Makarov et al. 2014) that the various types of $-\mathrm{OH}$ groups present in flavonoids play an important role to reduce the silver ion to silver metal and capping the metal through chelating by close presence of carbonyl and hydroxyl groups and also by catechol moiety of flavonoids. It has been also proposed (Ahmad et al. 2010) that the tautomeric transformations of flavonoids from the enol form to the keto form may release a reactive hydrogen atom that can reduce metal ions to form nanoparticles. On the one hand, DFT study shows (Trouillas et al. 2006) that bond dissociation energies of O$\mathrm{H}$ bond of $-\mathrm{OH}$ groups of catechol moiety of flavonoids are less than that of other $-\mathrm{OH}$ groups present in flavonoids. The results indicate that $-\mathrm{OH}$ groups of catechol moiety of flavonoids may take part in metal ion reduction. On the basis of foregoing discussion, for an example, taking quercetin as a flavonoid, the putative reaction path of reducing the $\mathrm{Ag}^{+}$and capping the nano- $\mathrm{Ag}$ may be outlined as in Scheme 1.

Reduction of $\mathrm{Ag}^{+}$ion into $\mathrm{Ag}$ nanoparticles using leaf extract of Psidium guajava was evidenced by visual change of colour of reaction mixture from colourless to yellow then to reddish brown (Fig. 2). The UV-Vis spectra (Fig. 3) confirmed the formation of $\mathrm{Ag}$ nanoparticles. The surface plasmon resonances (SPR) of silver nanoparticle were observed at $435 \mathrm{~nm}$. The intensity of the SRP peaks increases as reaction time increases, which indicates the increase in concentration of the silver nanoparticles. The result reflects that the Ag nanoparticles prepared by Psidium guajava leaf extract are stable without aggregation.

From the TEM images (Fig. 4), it is observed that most of the Ag nanoparticles are spherical in shape, and a few agglomerated Ag nanoparticles were also observed in some place. Figures also show that there is a variation in particle size and distribution of size. It may be noted that average particle size estimated was $40 \mathrm{~nm}$, and particle size ranges from 10 to $90 \mathrm{~nm}$. The size of these biosynthesized $\mathrm{Ag}$ nanoparticles are in conformity with the size of earlier reported biosynthesized Ag nanoparticles using the leaf of Coleus aromaticus, 40-50 nm (Vanaja and Annadurai 2013), using living peanut seedling, 30-100 nm (Raju et al. 2014), using leaf extract Petroselinum crispum, 30-32 nm 
Scheme 1 Outline of reaction path of reduction of $\mathrm{Ag}^{+}$ion (a) and capping of $\mathrm{Ag}$ nanoparticle (b) by quercetin

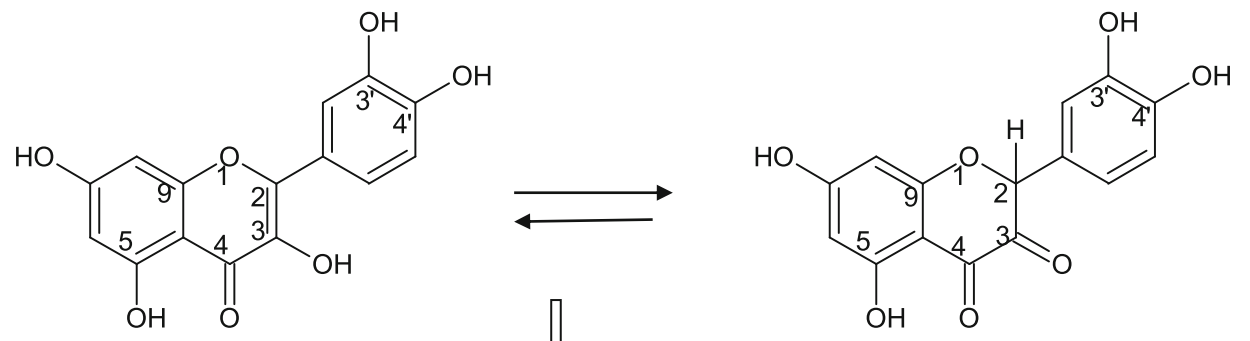

Keto

(a)

(b)

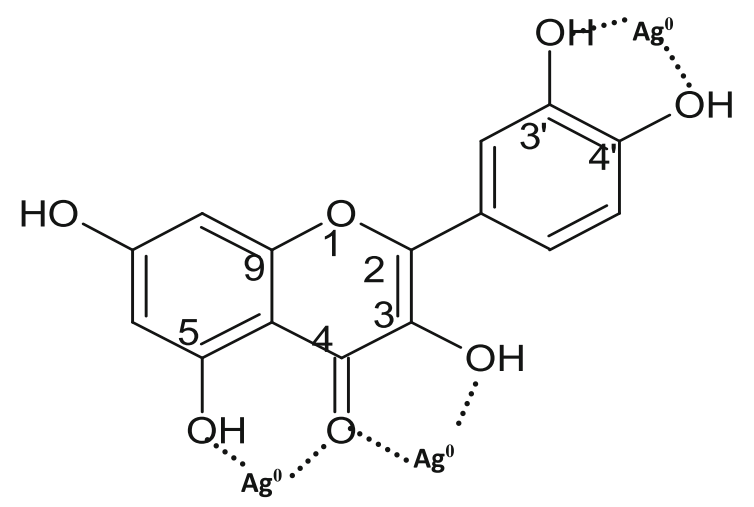

(Roy et al. 2014), using Justicia adhatoda L Leaf, 5-50 nm (Bose and Chatterjee 2015), etc.

In the present study, the potentiality of silver nanoparticles as a common antimicrobial substance has been evaluated against $P$. aeruginosa MTCC 741 by standard methods. $P$. aeruginosa is an opportunistic human pathogen, and the genus itself is a potent plant pathogen also. It produces soft rot disease in Arabidopsis thaliana (Walker et al. 2004) and Lactuca sativa (Rahme et al. 1997). The results of disc diffusion assays indicate that the antimicrobial activities of silver nanoparticles $(\mathrm{ZoI}=7-8 \mathrm{~mm})$ are as effective as silver ions ( $\mathrm{ZoI}=8-10 \mathrm{~mm})$, whereas the raw leaf extract has no visible inhibitory effect on $P$. aeruginosa MTCC 741 strain. However, the result of disc diffusion assays is too preliminary to conclude about the antibacterial properties of silver nanoparticles. The Agar cup assay method and serial dilution turbidity measurement assay methods are more sensitive than disc diffusion assay method. Table 1 shows that the results of agar cup assay reveal that biosynthesized silver nanoparticles using guava leaf extract have strong efficiency to inhibit (average $\mathrm{ZoI}=2.26-2.40 \mathrm{~cm}$ ) the bacterial growth. The serial dilution method has selective advantage over other method of assay. The results of serial dilution method are illustrated in Fig. 6. The nanoparticles when added to the liquid medium start their antibacterial activities in terms of inhibition of the growth of bacteria. This inhibition is measured in terms of optical density values (OD). The MIC 
Table 1 Result of agar cup assay method

\begin{tabular}{ll}
\hline $\begin{array}{l}\text { Concentrations of } \mathrm{AgNO}_{3} \text { solution are } \\
\text { used to synthesize } \mathrm{Ag} \text { nanoparticle }\end{array}$ & $\begin{array}{l}\text { Average zone of } \\
\text { inhibition }(\mathrm{cm})\end{array}$ \\
\hline $1.5 \times 10^{-3} \mathrm{M}$ & $2.40 \pm 0.153$ \\
$2.0 \times 10^{-3} \mathrm{M}$ & $2.33 \pm 0.177$ \\
$2.5 \times 10^{-3} \mathrm{M}$ & $2.26 \pm 0.208$ \\
\hline
\end{tabular}

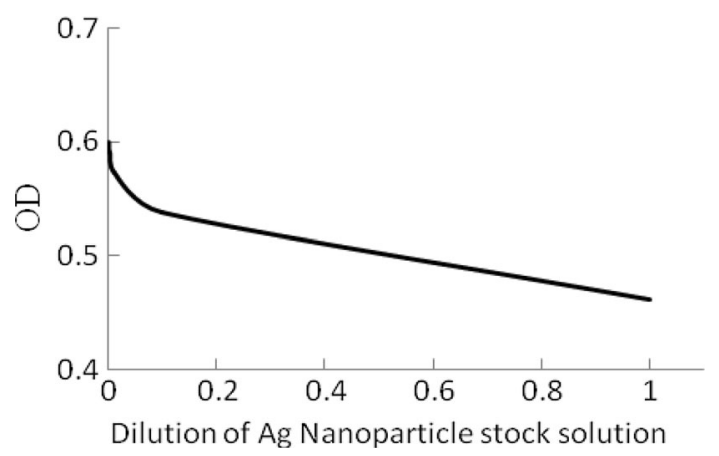

Fig. 6 Calculation of MIC of $\mathrm{Ag}$ nanoparticles (synthesized by reducing $\mathrm{AgNO}_{3}$ using guava leaf extract)

value indicates that the green synthesized silver nanoparticles using the leaf extract of guava can inhibit the growth of $P$. aeruginosa MTCC 741 strain at the concentration of $10^{-6}(\mathrm{M})$. This study is tuned with earlier reported studies: antibacterial activity of $\mathrm{Ag}$ nanoparticles on fish pathogen and other microbes (Gupta et al. 2014; Velmurugan et al. 2014, Mahanty et al. 2013).

Several mechanisms regarding antimicrobial activity of Ag nanoparticles have been proposed. It seems that sulphur and phosphorus containing proteins or enzymes or phosphorous moiety of DNA of bacterial system may be affected by the Ag nanoparticles which lead to the inhibition of enzyme system of the organism (Sulaiman et al. 2013). Le et al. (2012) clearly demonstrated that the Ag nanoparticles get attached to the cell surface of $E$. coli and $V$. Cholera and then penetrated into the cell, destroyed the cell cytoplasm and killed the organism. Le et al. (2012) also found that $\mathrm{Ag}$ nanoparticles significantly increase the cell permeability and affect the proper transport through plasma membrane. Thus, the regulation of transport through the membrane become disrupted which leads to the cell death.

In conclusion, this study revealed an economical, efficient and environment friendly route for green synthesis of Ag nanoparticles and evaluated the efficacy of the inhibitory effect of this biosynthesized Ag nanoparticles against $P$. aeruginosa. If further inhibitory studies of this biosynthesized Ag nanoparticles against other plant pathogenic pseudomonades like $P$. syringae, $P$. tolaasii and $P$. agarici agree with our present finding, then the green synthesized Ag nanoparticles could be more economical and promising alternate antibacterial agent in the field of agriculture for large-scale production.

Acknowledgments Authors acknowledge the UGC (ERO) Kolkata for providing financial help in terms of minor research project. Authors also acknowledge the help and support from Prof. N. C. Mondal, Visva-Bharati, WB, for providing bacterial strain. The authors are thankful to the reviewer for comments and suggestions.

Open Access This article is distributed under the terms of the Creative Commons Attribution 4.0 International License (http:// creativecommons.org/licenses/by/4.0/), which permits unrestricted use, distribution, and reproduction in any medium, provided you give appropriate credit to the original author(s) and the source, provide a link to the Creative Commons license, and indicate if changes were made.

\section{References}

Ahmad N, Sharma S, Alam MK, Singh VN, Shamsi SF, Mehta BR, Fatma A (2010) Rapid synthesis of silver nanoparticles using dried medicinal plant of basil. Colloids Surf B Biointerfaces 81:81-86. doi:10.1016/j.colsurfb.2010.06.029

Bose D, Chatterjee S (2015) Antibacterial activity of green synthesized silver nanoparticles using vasaka (Justicia adhatoda L.) leaf extract. Indian J Microbiol 55:163-167. doi:10.1007/ s12088-015-0512-1

Evanoff DD, Chumanov G Jr (2004) Size-controlled synthesis of nanoparticles. 1. "Silver-Only" aqueous suspensions via hydrogen reduction. J Phys Chem B 108:13948-13956. doi:10.1021/ jp047565s

Gnanadesigan M, Anand M, Ravikumar S, Maruthupandy M, Ali MS, Vijayakumar V, Kumaraguru AK (2012) Antibacterial potential of biosynthesised silver nanoparticles using Avicennia marina mangrove plant. Appl Nanosci 2:143-147. doi:10.1007/s13204011-0048-6

Gupta K, Barua S, Hazarika SN, Manhar AK, Nath D, Karak N, Namsa ND, Mukhopadhyay R, Kalia VC, Mandal M (2014) Green silver nanoparticles: enhanced antimicrobial and antibiofilm activity with effects on DNA replication and cell cytotoxicity. RSC Adv 4:52845-52855. doi:10.1039/c4ra08791g

Gutiérrez RMP, Mitchell S, Solis RV (2008) Psidium guajava: a review of its traditional uses, phytochemistry and pharmacology. J Ethnopharmacol 177:1-27. doi:10.1016/j.jep.2008.01.025

Le AT, Le TT, Nguyen VQ, Tran HH, Dang DA, Tran QH, Vu DL (2012) Powerful silver nanoparticles for the prevention of gastrointestinal bacterial infection. Adv Nat Sci Nanosci Nanotechnol 3:045007. doi:10.1088/2043-6262/3/4/045007

Mahanty A, Mishra S, Basu R, Maurya UK, Netam SR, Sarkar B (2013) Phytoextract-synthesized silver nanoparticles inhibit bacterial fish pathogen Aeromonas hydrophila. Indian J Microbiol 53:438-446. doi:10.1007/s12088-013-0409-9

Makarov VV, Love AJ, Sinitsyna OV, Makarova SS, Yaminsky IV, Taliansky ME, Kalinina NO (2014) "Green" nanotechnologies: synthesis of metal nanoparticles using plants. Acta Naturae $6: 35-44$

Merga G, Wilson R, Lynn G, Milosavljevic BH, Meisel D (2007) Redox catalysis on "Naked" silver nanoparticles. J Phys Chem C 111:12220-12226. doi:10.1021/jp074257w 
Navaladian S, Viswanathan B, Viswanath RP, Varadarajan TK (2007) Thermal decomposition as route for silver nanoparticles. Nanoscale Res Lett 2:44-48. doi:10.1007/s11671-006-9028-2

Nickel U, Castell A, Pöppl K, Schneider S (2000) A silver colloid produced by reduction with hydrazine as support for highly sensitive surface-enhanced Raman spectroscopy. Langmuir 16:9087-9091. doi:10.1021/la000536y

Ojewole JA (2005) Hypoglycemic and hypotensive effects of Psidium guajava Linn. (Myrtaceae) leaf aqueous extract. Methods Find Exp Clin Pharmacol 27:689-695. doi:10.1358/mf.2005.27.10. 948917

Rahme LG, Tan MW, Le L, Wong SM, Tompkins RG, Calderwood SB, Ausubel FM (1997) Use of model plant hosts to identify Pseudomonas aeruginosa virulence factors. Proc Natl Acad Sci USA 94(24):13245-13250. doi:10.1073/pnas.94.24.13245

Raju D, Paneliya N, Mehta UJ (2014) Extracellular synthesis of silver nanoparticles using living peanut seedling. Appl Nanosci 4:875-879. doi:10.1007/s13204-013-0269-y

Raveendran P, Fu J, Wallen SL (2003) Completely "Green" synthesis and stabilization of metal nanoparticles. J Am Chem Soc 125(2003):13940-13941. doi:10.1021/ja029267j

Roy K, Sarkar CK, Ghosh CK (2014) Plant-mediated synthesis of silver nanoparticles using parsley (Petroselinum crispum) leaf extract: spectral analysis of the particles and antibacterial study. Appl Nanosci. doi:10.1007/s13204-014-0393-3

Sahadevan R, Sivakumar P, Karthika P, Sivakumar Muralidharan N G, Devendran P (2013) Biosynthesis of silver nanoparticles from active compounds Quacetin -3-O-B-D-galactopyranoside containing plant extract and its antifungal application. Asian J Pham Clin Res 6:76-79

Shirtcliffe N, Nickel U, Schneider S (1999) Reproducible preparation of silver sols with small particle size using borohydride reduction: for use as nuclei for preparation of larger particles. J Colloid Interface Sci 211:122-129. doi:10.1006/jcis.1998.5980

Sondi I, Goia DV, Matijević E (2003) Preparation of highly concentrated stable dispersions of uniform silver nanoparticles. J Colloid Interface Sci 260:75-81. doi:10.1016/S00219797(02)00205-9
Sreeram KJ, Nidhin M, Nair BU (2008) Microwave assisted template synthesis of silver nanoparticles. Bull Mater Sci 31:937-942

Sulaiman GM, Mohammed WH, Marzoog TR, Al-Amiery AAA, Kadhum AAH, Mohamad AB (2013) Green synthesis, antimicrobial and cytotoxic effect of silver nanoparticles using Eucalyptus chapmaniana leaves extract. Asian Pac J Trop Biomed 3:58-63. doi:10.1016/S2221-1691(13)60024-6

Trouillas P, Marsal P, Siri D, Lazzaroni R, Duroux J (2006) A DFT study of the reactivity of $\mathrm{OH}$ groups in quercetin and taxifolin antioxidants: the specificity of the $3-\mathrm{OH}$ site. Food Chem 97:679-688. doi:10.1016/j.foodchem.2005.05.042

Vanaja M, Annadurai G (2013) Coleus aromaticus leaf extract mediated synthesis of silver nanoparticles and its bactericidal activity. Appl Nanosci 3:217-223. doi:10.1007/s13204-0120121-9

Vankar PS, Shukla D (2012) Biosynthesis of silver nanoparticles using lemon leaves extract and its application for antimicrobial finish on fabric. Appl Nanosci 2:163-168. doi:10.1007/s13204011-0051-y

Velmurugan P, Iydroose M, Lee SM, Cho M, Park JH, Balachandar V, Oh BT (2014) Synthesis os silver and gold nanoparticles using cashew nut shell liquid and its antimicrobial activity against fish pathogens. Indian J Microbiol 54:196-202. doi:10. 1007/s12088-013-0443-5

Walker TS, Bais HP, Déziel E, Schweizer HP, Rahme LG, Fall R, Vivanco JM (2004) Pseudomonas aeruginosa-plant root interactions. Pathogenicity, biofilm formation, and root exudation. Plant Physiol 134(1):320-331. doi:10.1104/pp.103.027888

Wang H, Qiao X, Chen J, Ding S (2005) Preparation of silver nanoparticles by chemical reduction method. Colloid Surf A 256:111-115. doi:10.1016/j.colsurfa.200412.058

Xie J, Lee JY, Wang DIC, Ting YP (2007) Silver nanoplates: from biological to biomimetic synthesis. Am Chem Soc Nano 1:429-439. doi:10.1021/nn7000883

Zamiri R, Zakaria A, Abbastabar H, Darroudi M, Husin MS et al (2011) Laser-fabricated castor oil-capped silver nanoparticle. Int J Nanomed 6:565-568. doi:10.2147/IJN.S16384 